\title{
THE EFFECTIVENESS OF DICTOGLOSS METHOD ON LISTENING SKILL OF NARRATIVE TEXT AT TENTH GRADE STUDENTS OF MA AL IMAN ADIWERNA TEGAL
}

\author{
Tuty Alawiyah \\ Ma Al Iman Adiwerna Tegal \\ e-mail: tutybissurebia@gmail.com \\ Farouk Imam Arrasyid \\ IAIN Syekh Nurjati Cirebon \\ Faroukarrasyid@gmail.com
}

\begin{abstract}
Many problems based on condition of learning listening at tenth grade students of MA Al-Iman Adiwerna Tegal, students difficult to understand the topic or, content of spoken. This research method is quantitative, that used quasi experiment design. The population was at the tenth grade students of MA Al-Iman Adiwerna Tegal with a total number of 90 students and 61 students were taken as sample. The data were collected by using multiple choice listening test (pre and post-test). The finding show the t-test result it can be seen that tcount is 2.289 and ttable $=1.671$. So, the researcher made the conclusions of the hypothesis that tcount is higher than ttable namely 2.571>1.684 an from formula of t-test shown that to > tt namely 0,026 $<0,05$, In other word, the Alternative Hypothesis (Ha) is accepted and the Null Hypothesis $(\mathrm{Ho})$ is rejected. It means that there is positive and significant effect of using dictogloss method on listening skill of narrative text. It means that there is positive and significant effect of using dictogloss method on listening skill of narrative text at Tenth Grade Students of Ma Al Iman Adiwerna Tegal.
\end{abstract}

Keyword: Dictogloss method, Listening Skill, Narrative Text. 


\section{BACKGROUND}

This research investigates students' listening skill. It was found out from students at MA Al-Iman Adiwerna Tegal, when the researcher observed and interview with English teacher of tenth grade students of MA Al-Iman Adiwerna Tegal on $2^{\text {nd }}$ June 2015, in that school researcher found there are problems in learning english, especially in learning listening about listening text of narrative text that faced students at tenth grade MA Al-Iman Adiwerna Tegal, students difficult when learn in listening of narrative text such as students lack in vocabulary it makes students difficult to get understanding when students listen English language. When students listen native speaker student feel difficult because, it make students difficult to understand what native speaker say and also students in tenth grade of MA Al-Iman Adiwerna Tegal they feel strange when hear the language of native speaker in audio because students felt lack in pronunciation. Learning listening at tenth grade students of MA Adiwerna Tegal, students difficult to understand the topic or, content of spoken because, students feel the native speaker in audio speak quickly and confuse when they listen from a tape or recorder by native speaker, but when students listen from the teacher originally as native speaker, they feel easy to understand the text. As stated by Brow (2006: 4), "listening is a complex activity, and people can help students comprehend what they hear by activating their prior knowledge. The next section will consider another way teachers can help ease the difficulty of listening: training students in different types of listening".

Students feel bored when learning listening because difficult to get information or the meaning what the speaker say, there are misunderstanding between listener and speaker because listener do not understand with foreign language. According to Nashruddin (2013:3), "Listening is difficult skill in second language learning. Many factors varying from the difference of sound between the second language learners and the second language he/she is learning".

In the learning listening students should pay attention first in the vocabulary, grammar, and pronunciation. When students listen foreign language but still less in the mastery vocabulary, students feel difficult to understand the meaning, from the grammar to students will be confused in the time, and also difficult to write the result of listening. To solve the problems at tenth grade students of MA Al-Iman Adiwerna Tegal researcher used dictogloss method to get achievement in learning listening especially in listening text about narrative text. In this method students can hear a text directly from the teacher with the clear pronunciation. Students feel easy to understand vocabulary and communicative each other. So students should really focus when listen speaker in order to students can get the information. Based on the problem in the listening must use the method that can help students to solve the problems in listening skill.

The researcher uses dictogloss method as the effective method to solve the problem above. According with Jacobs and Small (2003: 1), "dictogloss is a new way of dictation" which was developed by Ruth Wajnryb. Dictogloss, in term of objective and procedures, in different from dictation. Based on statement, dictogloss learner technique is very helpful in listening and learning about their ability to monitor 
students both in the classroom and outside the classroom "Dictogloss is a classroom dictation activity where learners listen to a passage, note down key words and then work together to create a reconstructed version of the text. It was originally introduced" Wajnryb (1990) in (Vasiljevic,. 2010: 43). "Dictogloss activities are a useful way of presenting new factual information to students, and encourage them to listen for key points and understand the listening" Indriyanti (2013:3).This method can use in many level and easy to used can make can improve in the vocabulary and can make communicative too. So, the researcher to make research that is "The Effectiveness of Dictogloss Method on Listening Skill of Narrative Text at Tenth Grade Stdents of Ma Al Iman Adiwerna Tegal."

The researcher found the problem about listening skill at tenth grade MA AlIman Adiwerna Tegal. The important of this research is to solve the problem on tenth grade Ma Al-Iman Adiwerna Tegal of problem on listening skill about listening text and help teacher to get the effective method to teaching listening.

\section{METHOD}

This research use Quantitative research, specific focus on survey and experimental modes of inquiry. Creswell (2009:17). In this quantitative experimental choose quasi experiment. Quasi-experimental designs do not include the use of random assignment. Researchers who employ these designs rely instead on other techniques to control (or at least reduce) threats to internal validity. We shall describe some of these techniques as we discuss several quasi-experimental designs (Frankle et al, 2008: 270). ), stated that "Experimental research procedures are ideally suited for quantitative research design." Experimental research is explaining whether an intervention influences an outcome for one group as opposed to another group. The research to choose this design because research experiment in both the control group and the experimental group were given pre-test and post-test and sample which use both of them obtained by quasi experimental.

In the following is quasi-experimental design by (Creswell, 2012: 310): The Pretest-Posttest Control Group Design. The dashed line separating the parallel rows in the diagram of the non-equivalent control group indicates that the experimental and control groups have not been equated by randomization - hence the term 'nonequivalent'. The technique of collecting data researcher just used test for students, this to get the real information. According to Kernerman (1996: 630) state that "test is a set of questions or exercises intended to find out a person's ability, knowledge etc". Before test is given to respondents, the test need to validation to know the validation, reliabilities and index the difficulties of test. After the questions are valid so researcher put the valid test to be question of pre-test and post-test.

a) Pre-test is administered at the beginning of the research. The aim of this test to gain the data of student's basic listening skill. It is carried out before the researcher gives the material (treatment) use dictogloss method. The students given a listening test in a form of stimuli test. Give the treatment that is by using dictogloss method. 
b) Post-test is administered at the end of the research. The purpose of this test is to find out the result after the students get the material (treatment) used dictogloss method.

The researcher tried to use test as instrument of collecting data. Students give test is tenth grades at class X.1 and class X.3. Students listen teacher as native speaker, the material about narrative text. Where the students are listen about narrative text. The test conducted in two weeks and duration is 70 minutes. In this test researcher choose two class as the collecting data because use quasi experimental, so should used two class and researcher using at tenth grade in class X.1 and X.3, class $\mathrm{X} .1$ as the control class and class X.3 as the experiment class.

The test which using in this research is an objective test (multiple choice) with every items has four choice alternative ( $a, b, c$ and d) and the score of technique, perscore in right answer is one point and if wrong is zero. The organizer of test with two times, that is pre-test and post-test, in the total 50 questions in type of multiple choices. The test was conducted by the researcher before teaching using dictogloss method on listening skill. This test was to know the students' listening skill before students got treatment. The result of the test so find in reliabilities, different of energy, and difficult in answer and paper of test save.

\section{Data Analysis}

In the step choice the research approach, have found a several design experimental. To significant testing, should be used t-test. An experimental method using treatment and control group without using treatment, so the researcher chooses the data analysis that is started by Sudijono (2010: 284). The formula is as follows:

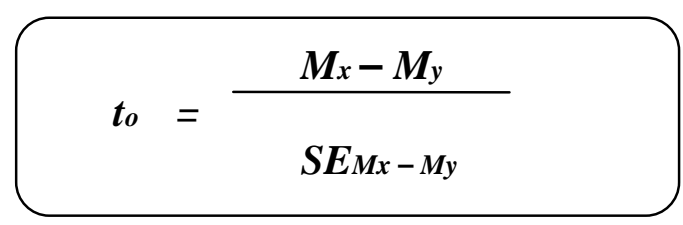

Note:

to $=$ tobservasi

$M \mathrm{x}-M \mathrm{y}=$ mean of experiment group and control group

$S E M x-M y=$ standard error mean sample of experiment group and control group

The formula of degrees of freedom ( $d f$ or $d b$ ) as follows:

$$
\begin{aligned}
& \text { Note: } \\
& d f=\left(\mathrm{N}_{1}+\mathrm{N}_{2}\right)-\mathbf{2} \\
& \mathrm{N} 1=\text { degrees of freedom }
\end{aligned}
$$




\section{Hypothesis}

Sugiyono (2013: 85) explain the definition of hypothesis in statistic is the statistics arguments or declaration about population of parameter. Statistic hypothesis of this research are: Ho: $\rho=0$ there is no positive and significant influence of the application of Dictogloss method on listening skill. Ha: $\rho \neq 0$, there are positive and significant influence of the application of Dictogloss method on increasing listening skill.

\section{The Research Findings And Discussion}

To know the difference of listening skills significantly between used Dictogloss method (experiment class) with do not used Dictogloss method (control group) at MA Al-Iman Adiwerna Tegal, must know some gain score obtained which got of students who use Dictogloss method with do not used Dictogloss method. In this study conducted two tests with the same problem, namely the pretest and posttest. It is the test results that calculation the researcher uses software SPSS v.2.2.0:

\section{Table 4.5}

The Data of the Students' listening skills using Dictogloss method and do not using Dictogloss method.

\begin{tabular}{|c|c|c|c|c|c|}
\hline \multicolumn{6}{|c|}{ Statistics } \\
\hline & & $\begin{array}{c}\text { pretest } \\
\text { eksperiment } \\
\text { class }\end{array}$ & $\begin{array}{c}\text { postest } \\
\text { eksperiment } \\
\text { class }\end{array}$ & $\begin{array}{c}\text { pretest } \\
\text { control class }\end{array}$ & $\begin{array}{c}\text { postest } \\
\text { control class }\end{array}$ \\
\hline \multirow[b]{2}{*}{$\mathrm{N}$} & Valid & 31 & 31 & 30 & 30 \\
\hline & \begin{tabular}{|l} 
Missi \\
ng
\end{tabular} & 0 & 0 & 1 & 1 \\
\hline \multicolumn{2}{|c|}{ Mean } & 68.4516 & 79.0323 & 66.9333 & 74.8667 \\
\hline \multicolumn{2}{|c|}{ Median } & 66.0000 & 78.0000 & 66.0000 & 74.0000 \\
\hline \multicolumn{2}{|c|}{ Mode } & 70.00 & 72.00 & 60.00 & $70.00^{\mathrm{a}}$ \\
\hline \multicolumn{2}{|c|}{ Minimum } & 58.00 & 64.00 & 58.00 & 60.00 \\
\hline \multicolumn{2}{|c|}{ Maximum } & 90.00 & 96.00 & 80.00 & 90.00 \\
\hline \multicolumn{2}{|c|}{ Sum } & 2122.00 & 2450.00 & 2008.00 & 2246.00 \\
\hline
\end{tabular}

Based on the result of SPSS output score of the pretest students with the score obtain used Dictogloss method the minimum score is 58, the maximum score is 90 , the average (mean) is 68.4 , and total score 2122 . While the score of students post-test that used dictogloss method obtained the minimum score is 64 , the maximum score is 96, Average (mean) 79.03, and total score is 2450.

Based on the results of SPSS V 0.2.2.0 output score of the pre-test students who do not used Dictogloss method obtained the minimum score is 58, the maximum score is 80 , the average (mean) of 66.9 , and total score 2008 . While the score of posttest students do not used Dictogloss method obtained the minimum score is 60 , the score of a maximum of 90 , average (mean) of 74.86, and total score is in 2246. 
From the data pretest and posttest gain score is taken to know increasing of listening skill between two classes. The following is description of analysis result of gain:

Table 4.6

Statistics Gain of Analysis

\begin{tabular}{|l|l|r|r|}
\hline \multicolumn{2}{|l|}{} & $\begin{array}{c}\text { Gain eksperiment } \\
\text { class }\end{array}$ & \multicolumn{2}{c|}{$\begin{array}{c}\text { Gain control } \\
\text { class }\end{array}$} \\
\hline \multirow{2}{*}{$\mathrm{N}$} & Valid & 31 & 30 \\
\cline { 2 - 4 } & Missing & 0 & 1 \\
\hline Mean & .3474 & .2437 \\
\hline Median & .3000 & .2550 \\
\hline Mode & $.18^{\mathrm{a}}$ & .11 \\
\hline Minimum & .10 & -.18 \\
\hline Maximum & .71 & .60 \\
\hline Sum & 10.77 & 7.31 \\
\hline
\end{tabular}

a. Multiple modes exist. The smallest value is shown

Based on the results of SPSS V 0.2.2.0 output on students gain score with the score obtained using the method Dictogloss average (mean) 0.35 . While the students gain score did not used Dictogloss method average scores obtained (mean) 0.24.

Furthermore, if there is a significant difference between the listening skills that used Dictogloss method with did not used Dictogloss method at MA Al-Iman Adiwerna Tegal, then tested the hypothesis. But before hypothesis testing, first normality tested and homogeneity tested of two variances test to find out further analysis of the data pretest and posttest both classes. Here are the results of normality pretest and posttest from the class that uses Dictogloss method with do not used Dictogloss method.

This difference can be seen from the difference in the average (mean) of $\mathrm{N}$ Gain, wherein N-Gain experimental class got an average rating of 0.35 , while the $\mathrm{N}$ Gain control class solidified average score of 0.24 , so the result is 0.11 . This means classes that use Dictogloss method is better than the class that does not use Dictogloss method to improve listening skills. So from the statement above that used of Dictogloss method is effective on listening skills.

The data pre-test and post-test class that uses Dictogloss method distribution normal, pre-test and post-test class did not used Dictogloss method also normal distribution, and score of pretes and posttest distribution is homogeneous, and is testing the effect of a treatment of the two groups, in which the first group is a group that uses dictogloss method that the second is a group without using Dictogloss method, then to test the hypothesis using statistical parametric, so that in testing SPSS used Independent Sample Test (t-test) to determine the difference of these two variables. Here are the results of the analysis:

Based on the table Independent Sample Test note that the significance value (Sig.) Is 0.026 . When compared, then the value will be less than $0.05(0.026<0.05)$, this means that Ho is rejected, which there is difference listening skills are significant 
differences between the used Dictogloss method by which without using Dictogloss method at MA Al-Iman Adiwerna Tegal.

On the other hand, the researcher used formula of t-test. The researcher calculated based on the step of the $t$-test, as follows:

a. Determining Mean of Variable $X$, with formula:

$$
M \mathrm{x}=\frac{\Sigma X}{N}=\frac{199}{31}=6.41
$$

b. Determining Mean of Variable $Y$, with formula:

$$
M \mathrm{y}=\frac{\Sigma Y}{N}=130=4.3
$$

c. Determining of Standard of Deviation Score of Variable $X$, with formula:

$$
S D x=\sqrt{\frac{\Sigma x^{2}}{N}}=\sqrt{\frac{251}{31}}=\sqrt{8.096}=2.84
$$

d. Determining of Standard of Deviation Score of Variable $Y$, with formula:

$$
S D \mathrm{y}=\sqrt{\frac{\Sigma y^{2}}{N}}=\sqrt{\frac{114}{30}}=\sqrt{3.8}=1.94
$$

e. Determining Standard Error Mean of Variable $X$, with formula:

$$
S E M x=\frac{S D \mathrm{x}}{\sqrt{N-1}}=\frac{2.84}{\sqrt{31-}} 1=\frac{2.84}{\sqrt{30}}=\frac{2.84}{5.47}=0.51
$$

f. Determining Standard Error Mean of Variable $Y$, with formula:

$$
S E M y=S D y=1.94=1.94=1.94=0.36
$$

g. Determining Standard Error Mean of Difference Mean of Variable $X$ and Mean of Variable $Y$, with formula:

$$
\begin{aligned}
S E M x & -M y=\sqrt{S E M x^{2}+S E M y^{2}}=\sqrt{(0.51)^{2}+(0.36)^{2}} \\
& =\sqrt{0.26+0.12} \\
& =\sqrt{0.38} \\
& =0.61
\end{aligned}
$$

h. Determining to with formula:

$$
\text { to } \frac{M \mathrm{x}-M \mathrm{y}}{S E M \mathrm{x}-M \mathrm{y}}=\frac{0.41-4.3=2.11}{0.61} \frac{4.45}{0.61}
$$

i. Determining $t$-table in significant level $5 \%$ and $1 \%$ with $d f$.

$$
\begin{aligned}
d f & =(N 1+N 2)-2=(31+30)-2 \\
& =61-2 \\
& =59
\end{aligned}
$$

$d f=59$ (see the table of " $\mathrm{t}$ " values at the degree of significant of $5 \%$ and $1 \%$ ). Because the value of 59 is not mentioned in the table, the researcher as uses the closer value to 59 as degree of freedom $(d f)$. The value of 59 mentioned in the table of " $\mathrm{t}$ " as follows:

$t$-table $(\mathrm{tt})$ at significance $5 \%=2.00$

$t$-table $(\mathrm{tt})$ at significance $1 \%=2.65$

Based on the calculation above, it is known that the result of t-test from control group and experiment group is 3.45, the degree of freedom is 59 (see the table of " $t$ " values at the degree of significant of 5\%). Because the value of 59 is not mentioned in 
the table, the researcher as uses the closer value to 59 as degree of freedom $(d f)$. The value of 59 mentioned in the table of (table $5 \%=2.00$ and $1 \%=2.65$ ), so $2.00<3.45>2.65$. It means that to higher that $\mathrm{tt}$ (to $>\mathrm{tt}$ ) and $\mathrm{Ha}$ is accepted and Ho is rejected. So, there is positive and significant effect of using dictogloss method on listening skill of narrative text.

\section{Testing Hypothesis}

The data obtained from the experiment class and the control class was calculated by using the independent sample $t$-test. As stated by Sudijono (2010: 301) that: to > tt : The alternative hypothesis (Ha) is accepted and the null hypothesis (Ho) is rejected. It means there is positive and significant effect of dictogloss method on listening skill of narrative text. to $<\mathrm{tt}$ : The alternative hypothesis $(\mathrm{Ha})$ is rejected and the null hypothesis (Ho) is accepted. It means there is no positive and significant effect of using dictogloss method on listening skill of narrative text. Based on the result of statistic calculation by using formula, it is obtained that the value of to is 3.45 and the degrees of freedom $(d f)$ is 59 obtained from $(\mathrm{N} 1+\mathrm{N} 2-2)=(31+30-2)$ $=59$. The value of 38 on the degree of significance of $5 \%$ and $1 \%$ the values of degrees of significance are not mentioned in the table, the researcher used the closer value to 59 as degree of freedom $(d f)$, it is 60 . So, tt at significance $5 \%=2.00$ and $t \mathrm{tt}$ at significance $1 \%=265$. By comparing the values of to $=3.45$ and $t \mathrm{tt}=2.00$ and 2.65. Therefore, the researcher made the conclusions of the hypothesis that to is higher than tt namely $2.00<3.45>2.65$.

On the other hand, the result of t-test by using SPSS, the researcher obtained tcount more than ttable $(2.289>1.671)$ which Ha is accepted and Ho is rejected. The significant (2-tailed) or probability value is 0.026 (where $0.026<0.05$ ). So, the alternative hypothesis (Ha) is accepted and the null hypothesis (Ho) is rejected. It means there is positive and significant effect of using dictogloss method on listening skill' of narrative text at tenth grade of MA Al-Iman Adiwerna Tegal.

\section{DISCUSSION}

Based on the result of the study, the following interpretations and discussions are presented to strength the value of the study. First, the result of the study showed a statistically significant difference in listening skill achievement between the students who were taught using Dictogloss method and those who were not. It was proven by the mean score posttest of experimental group $(79,03)$ was higher than the mean score posttest of control group (74.86). It was also assumed that Dictogloss method gave significant contribution in increasing students' listening skill.

This view is similar to the first activity which called warming up. On this activity, the researcher activated the students' background knowledge about the narrative text that they will hear later. It is done by asking some simple questions that related to the text. For example, the researcher will show the queen' pictures and ask the students about their knowing of it. It help the students when they comprehend the text because they have background' knowledge about it. 
Moreover, the activities of Dictogloss help the students to be more active and conscious. For the example, when the dictation was done, the students listened to the text carefully. It makes them focus to the text and try to get the main idea of the text. The dictation's activity helps them to comprehend the text easily. The students try to find the key words that they can use in the next activity. Although dictation is an old way but it is the effective way to practice the students in listening.

The alternative hypothesis claimed that Dictogloss method is effective for teaching listening skill which is marked by the successful learning and students' mastery. It could strength the previous theory which state by Wajnryb (1990: 27) "pointed out that Dictogloss is an effective way to practice grammar and vocabulary. Dictogloss can be an effective way to teach listening and improves the student' comprehension in listening".

The null hypothesis which claimed that dictogloss method is an effective for learning listening skill is proven. So the result of this result received. In conclusion, this method is effective for teaching listening skill, because it has many benefits for students and make the teaching process more interesting. Students more interested, they feel easy to understand the meaning of the text which they listen. Because exactly students difficult to understand and get information to can comprehension in listening from native speaker which students fell more difficult to understand. Then, Dictogloss method can help the students to increase their motivation, access what they know, decide what they want to learn and whether it is likely to be in the passage. So, it made students easy to learn listening especially in narrative text. In conclusion, this method is effective to increase students' ability in listening skill.

\section{CONCLUSION}

The result findings shows the average score that the achievement of students' listening skill before used Dictogloss method is 68.45 and the achievement of students' listening skill after used Dictogloss method is 79.03, it means that the achievement after the method higher than before it is $79.03>74.86$ while the students' ability after using Dictogloss method was increased with the average 79.03 it mean the score is goodfor experiment class and 74.86 it mean good for control class. Hence, this strategy is effective to use inteaching listening skill. It is proven by the t-test which used to analyze the statistical data. Here the independent sample t-test is used, because the data is comes from the different group. The finding show the $\mathrm{t}$ test result it can be seen that tcount is 2.289 and ttable $=1.671$. So, the researcher made the conclusions of the hypothesis that tcount is higher than table namely $2.571>1.684$ an from formula of t-test shown that to $>$ tt namely $0,026<0,05$, In other word, the Alternative Hypothesis (Ha) is accepted and the Null Hypothesis (Ho) is rejected. It means that there is positive and significant effect of using dictogloss method on listening skill of narrative text at Tenth Grade Stdents of Ma Al Iman Adiwerna Tegal. 


\section{REFERENCES}

Arikunto, Suharsimi. 2010. Procedure PenelitianSuatuPendekatanPraktik. Jakarta: PT. RinekaCipta.

Asmawati, Dede. 2013.Using Dictogloss To Improve Students' Listening Comprehension At The 2nd Grade Class Xi A 3 Of Sman 8 Kotabengkulu In 2011/2012 Academic Year:Bengkulu. Bengkulu.Universitas.

Brown, H. Douglas. 2000. Teaching by Principles an Interactive Approach to Language Pedagogy. San Francisco, California: Longman.

Brown, H.Doughloges.2003. Language Assessment: Principle and Classroom Practice. . Longman Press: California.

Brown, Gillian. 2001. Listening to Spoken $2^{\text {nd }}$ edition. British Library Cataloguing: British. UK: Cambridge University Press.

Buck, G. 2001. Assessing Listening. Cambridge: Cambridge University Press.

Christopher, Harwood.2008. A Classroom experiment: Using Dictogloss.

Cohen, Louis. Manion, Lawrence . Morrison, Keith. 2007. Research Methods in Education. Routledge: Madison Avenue, New York.

Creswell, John W. 2009. Research Design: quatitative, Qualitative and Mixed Method Approach. $\left(3^{\text {rd }} \mathrm{Ed}\right)$. Los Angeles: SAGE Publication.

$\mathrm{Du}, \mathrm{Xia}$ yu.2011.On the Multimedia Teaching in College English Listening. Academy: Phoenix ELT.

Eka, Juwita, Arief, Ayuliva Adnan. 2013.The Use of Dictogloss Method In Teaching Listening A Hortatory Exposition Text At Senior High Scool. Universitas Negeri Padang: Padang.

Fraenkel, Jack. R, Norman E. Wallen. 2009. How to design and evaluate research in education. New York: McGraw-Hill.

Hamalik, Oemar. 2009. Proses Belajar Mengajar. Jakarta: PT Bumi Aksara.

Indriyanti, Dewi. 2013. Teaching Listening Using Dictogloss to Improve Students' Listening Skill at The Eighth Grade of SMP Negeri 1 Pangenan. Unpublished.Swadaya Gunung Jati University.

Jacobs, George and Small, J. 2003. Combining Dictogloss and Cooperative Learning to Promote Language Learning. The Reading Matrix.

Kernerman, Lionel. (1996). Password: English Dictionary For Speakers Of Bahasa Indonesia. Jakarta :KesaintBalanc

Kondo, Makoto et al. 2009. Development of a Dictogloss System Oriented for Focus on Form. Shizuoka University: Japan.

Kothari. C. R. 2004. Research Methodology Method and Technique.Second Revised Edition. New Delhi: New Age International.

Nashruddin,Wakhid.2013.Understanding the Teaching of Listening andSpeaking: Understanding Students Need State University of Malang Pess: Malang.

Nasution, S. 2012. Didaktik Asas-Asas Mengajar. Jakarta: PT Bumi Aksara.

Nunan, D. 1991. Language Teaching Methodology: a Textbook for Teacher. London

Oanah, Tran Thi. 2011. The use of songs to improve listening skills for students at ITC Foreign Language Centre in Hai Duong. Unpublished. University of Language and International Studies.Press.Cambrige.Publisher:Finlandia. 
Renandy,Willy A. 2013.Effective Approaches to Teaching Listening: Chinese EFL Teacher's Perspectives. Nayang Technological University: Singapore.

Richards,Jack C.2008.Teaching Listening and Speaking From Theory to Practice.Cambridge university press: New York.

Rost, M. 2002. Teaching and Researching Listening. London, UK: Longman.

Stave, Brown. 2006. Teaching Listenig. New York:Cambridge University press.

Sudijono, Anas. 2010. Pengantar Statistik Pendidikan. Jakarta: Rajawali Pers.

Sudjana, Nana. 2010. PenilaianHasil Proses BelajarMengajar. Bandung: PT Remaja Rosdakarya.

Suryani, Sri.2012. Improving Students' Listening Skills Through Varied Listening Tasks In A Language Laboratory At Smp N 2 Yogyakarta.Yogyakarta: Yogyakarta State University.

Tunikmah, Kholishah. 2012. Listening Comprehension Of The Eighth Grade Students Of SMP 2 Bae In The Academic Year 2011/2012 Taught By Using Partial Dictation of BBC Learning English. Unpublished. Muria Kudus University.

Ur, P. 1998. Teaching Listening Comprehension.UK: Cambridge University Press.

Vasiljevic, Zorana. Dictogloss as an Interactive Method of Teaching Listening Comprehension to L2 Learners. English Language Teaching Vol 3, no 1 March 2010. Bunkyo University:Japan.

Wajnryb, R. 1990. Grammar Dictation. Oxford: Oxford University Press.

Wulandaari, Fitri. 2011. Improving students' Listening ability Using Spot TheDictogloss technique. Surakarta: SebelasMaret University. 